\title{
Evaluation of Policy Implementation at Norm Strategy Criteria Procedure Safety Management System that Influence the Safety Culture in Building Construction, Housing, Waterworks, Road and Bridge Project in Indonesia
}

\author{
Yusuf Latief*, Rossy Armyn Machfudiyanto*, Brain Harryanto*, \\ Cahyadi Santoso* \\ *(Department of Civil Engineering, Universitas Indonesia, Kampus UI Depok, Jawa Barat, Indonesia
}

\begin{abstract}
Unideal Safety culture in Indonesia requires an evaluation of policy implementation refers to the construction safety regulation, Ministry Regulation 05/PRT/2014. Out of Norms, Standards, Procedures and Criteria (NSPK), we only have Norms and Procedure. As for Standard and Criteria are still being planned. This research on building, housing, water resource, roads and bridges construction at the Ministry of General Works and Housing resulted in having significant relation between safety policy implementation dimension (Monitoring and sanction / penalty) and safety culture dimensions (behavior, safety cost, policy, leadership, man, and strategy). Recommendations for policy improvement are obtained from review and implementation strategy of the significant relation between safety policy implementation dimension and safety culture dimensions.
\end{abstract}

Keywords - Safety Culture, Construction Project, Safety Management System, Improvement Policies

\section{INTRODUCTION}

Poor safety culture construction in Indonesia is a result of the poor level of policy management systems (SMS). What is meant by Work Safety Management according to Kirwan (1998) is a set of policies, strategies, practices, procedures, roles and functions related to job safety. Meanwhile, according to Muniz (2007), the Safety Management System is more than just "paper system" policies and procedures and Mearns (2003) concludes that the safety management is a mechanism that is integrated within the organization and is designed to control hazards that may affect the safety and health of workers. Wilson and Koehn (2000) see further than the process and concluded that the safety management is a process control policy safety, procedures, and practices relating to safety at the project site (Choudhry, Fang, \& Lingard, 2008). Internationally Policy Settings Occupational Health and Safety are rules implementing Safety Management System and Occupational Health, published by the ILO in 1961, whereas in the US we know the Occupational Health and Safety Assessment Series (OHSAS), in the UK with British Standard (BS) and Australia as well New Zealand with AS / NZS 4801. in Indonesia, we know the Occupational Safety and Health Management System (SMK3). Data related to the implementation of policies SMK3 mention that construction companies that implement only $27.43 \%$ in all areas in Indonesia with all of unsecured category. So, we need an evaluation of policy implementation $\mathrm{K} 3$ construction refers to the national policy set of rules that can be norms, standards, procedures and / criteria (NSPK). SMK3 generally stipulated in Government Regulation 50 of 2012 on the safety of Application Management System and Occupational Health and for the construction field is set in the Minister of Public Works No. 05 / PRT / M / 2014 on Guidelines for Safety and Health Management System (SMK3) Construction field of Public Works.

Based on the discussion of policy evaluation SMK3 and safety culture, the identification of problems that occur in the construction field are as follows, application SMK3 in building construction, housing, waterworks, roads and bridges in Indonesia has not been effective, lack of implementation of the law (law enforcement) and sanctions for construction companies that do not implement SMK3, it should be an increase in the policy (policy improvement) in the safety culture in the building construction, housing, waterworks, roads and bridges in Indonesia. The purpose of this study was to:

1.Identify K3 policies relating to NSPK in Indonesia to improve the safety culture.

2.Determining the relationship between policy implementation K3 NSPK the safety culture in construction projects. 
3.Increase K3 policies on building construction, housing, waterworks, roads and bridges to improve safety culture.

\section{THEORITICAL REVIEW}

Evaluations are usually intended to assess the extent to which the effectiveness of public policies in order to be accountable to their constituents. The extent to which the purpose is achieved as well as to see how far the gap between expectations with reality. According to Anderson in Winarno (2008: 166), in general it can be said as a policy evaluation activities regarding estimates or judgments include the substance of policy, implementation and impact of the implementation of the policy. According to Lester and Stewart (Winarno, 2008: 166) the policy evaluation can be divided into two different tasks, the first task is to determine the consequences posed by a policy by describing its effects. While the second task is to assess the success or failure of a policy based on a standard or predefined criteria. Evaluation of policy is a question of fact to be a good measurement as well as assessment of the stage of policy implementation and the results (outcome) or impact (impact) on the workings of a policy or a specific program, so to determine what steps can be taken in the future. In reviewing the implementation of public policy, Edward III began by asking two questions, namely: Is the initial condition for the successful implementation of the policy? Is the basic obstacles successful implementation of the policy? George C. Edward III tries to answer two questions by examining four factors or variables of policies, namely the bureaucratic structure, resources, communications, disposition. The dimension that measuring tool for the evaluation of the implementation of the policy are as follows: 1) Communication, 2) Resources, 3) Disposition, 4) Structure Bureaucracy, 5) Weak of Implementation Policy, 6) Costs, 7) Supervision, 8) Audit, 9 ) Sanctions.

In 2004, Ho and Zeta learn the culture of safety in the construction industry of Hong Kong, and has set four key cultural factors (environmental, behavioral, organizational, and people) that affect the safety culture of construction. They concluded that the safety culture and its significance varies from one country to another due to cultural differences. Indeed, workers may behave differently because of differences in their backgrounds (race, nationality, religion, and society). According to Hofstede (1980), cultural differences based on five dimensions of value; power distance, uncertainty avoidance, individualism against collectivism, masculinity against femininity, and the long-term than short-term focus. Model of safety culture by Ho and Zeta (2004) shaped table with four major construction safety culture factors (environmental, behavioral, organizational, and people) into its four legs. It states that the organization's safety culture will fail (cannot stand) if it does not have the support of each of these factors. In 2005 (Suraji) stated that paradigm changes required safety into construction safety for the sake of reduction and mitigation of risks of occupational accidents in the construction project. Stated that the construction safety is not just the affairs of the contractor, but the affairs of all parties involved in the implementation of the construction cycle. According to the OHSAS 18001: 2007, occupational safety and health are the conditions and factors that affect the safety and health of workers, guests, or others in the workplace. According Suraji (2009), there are four principles construction safety, namely; worker safety, public safety, property safety, and environmental safety. The dimensions of safety culture that will be affected by the implementation of policies Management System Occupational Health and Safety (SMK3) construction in the vicinity of the project the Ministry of Public Works and Public Housing is 1) Leadership, 2) policy, 3) Strategy, 4) Workers, 5) Process, 6) Behavior, 7) Cost K3, 8) Systems Contracts, 9) System Values and 10) Partnership. Each dimension forming the abovementioned safety culture will be seen to do with the implementation of policies SMK3 construction. Relations or influence policy implementation SMK3 with significant safety culture Which according to the survey respondents and data processing Structural Equation Modelling (SEM).

\section{RESEARCH METHOD}

Survey research consisted of two phases, namely the study of literature and empirical process. At this stage of the study of literature required a good knowledge of the various elements of research through the study of a wide variety of literature sources, especially journals that discussed the topic of implementation of the policies and culture SMK3 construction safety (safety culture). Based on these studies will be collected knowledge about the concepts, and theoretical research that will be formulated theoretical relationships are good. At this stage of empirical study further examined the relevant knowledge of the variables to be tested, hypotheses and operational definition that operational picture of the data to be collected in a study can be illustrated clearly. The case study, is one way of empirical study of the problem by following a series of procedures that have been specified before. Before getting into the case study, the initial approach to survey research conducted using questionnaires and structured Interview 
experts to a sample of respondents. The first stage in a series of such procedures is a research design which is logical links between the data to be collected with the initial question and especially with the answers on these questions (K.Yin, 2003).

\section{RESEARCH RESULT}

Based on the tabulation tables and construct validation of the content above, it was found that Dimension Implementation has 9 (nine) Dimensions / Dimensions Variable Safety Culture has 10 (ten) Dimensions / Variables. Here is the end of the questionnaire results of the validation process experts.

Table 1. Dimension of Implementation Policy

Safety Management System in Contraction

\begin{tabular}{|c|c|c|}
\hline \multicolumn{3}{|c|}{ Enterprise } \\
\hline Dimension of Implementation policy & Code & Indicators \\
\hline \multirow[t]{3}{*}{\begin{tabular}{|l} 
Communnication \\
\end{tabular}} & $\mathrm{x} 1.1$ & Transmision of policy \\
\hline & $\mathrm{X} 1.2$ & Clarity of policy \\
\hline & $\mathrm{x} 1.3$ & Concistency of policy \\
\hline \multirow[t]{4}{*}{ Recources } & $\mathrm{X} 2.1$ & Staff \\
\hline & $\mathrm{X} 2.2$ & Information \\
\hline & $\mathrm{X} 2.3$ & Authority \\
\hline & $\mathrm{X} 2.4$ & Facilities \\
\hline \multirow[t]{2}{*}{ Dispotition } & $\mathrm{x} 3.1$ & Appointment of bureaucrats \\
\hline & $\times 3.2$ & Incentive \\
\hline \multirow[t]{2}{*}{\begin{tabular}{|l} 
Structure of bureaucratic \\
\end{tabular}} & $\mathrm{X} 4.1$ & Standard Operating Procedure \\
\hline & $\mathrm{X} 4.2$ & Fragmentation \\
\hline \multirow[t]{2}{*}{ Weak Implementation of Policy } & $\mathrm{x} 5.1$ & The number of work accident \\
\hline & $x 5.2$ & Survey \\
\hline \multirow[t]{4}{*}{ Cost of safety } & $\mathrm{x} 6.1$ & the cost of implementation of the safety \\
\hline & $\mathrm{x} 6.2$ & Eficiency \\
\hline & $\mathrm{x} 6.3$ & Adequacy cost of safety \\
\hline & $\mathrm{x} 6.4$ & Flattening cost of safety \\
\hline \multirow[t]{3}{*}{ Supervision } & $x 7.1$ & Availability supervisor \\
\hline & $\mathrm{x} 7.2$ & Intensification supervisor \\
\hline & $\mathrm{x} 7.3$ & Auditor safety management system \\
\hline \multirow[t]{3}{*}{\begin{tabular}{|l} 
Auditing \\
\end{tabular}} & $\mathrm{x} 8.1$ & Internal Auditor \\
\hline & $\mathrm{x} 8.2$ & Intitutional auditing safety system \\
\hline & $\mathrm{x} 8.3$ & Eksternal auditing safety system \\
\hline \multirow[t]{3}{*}{\begin{tabular}{|l|} 
Sanction \\
\end{tabular}} & $\mathrm{x} 9.1$ & Implementation \\
\hline & $x 9.2$ & Sanction againts Commitment maker official \\
\hline & $\mathrm{x} 9.3$ & Sanction againts contractor \\
\hline
\end{tabular}

The purpose of the use SmartPLS 3.0 is to estimate the relationship in the form of causalpredictive inter-dimensional construction safety culture with that purpose in environmental performance improvement K3 owner-state enterprise. for part of the research process have explained the thought process in building hypotheses in the form of a model relationship as follows.

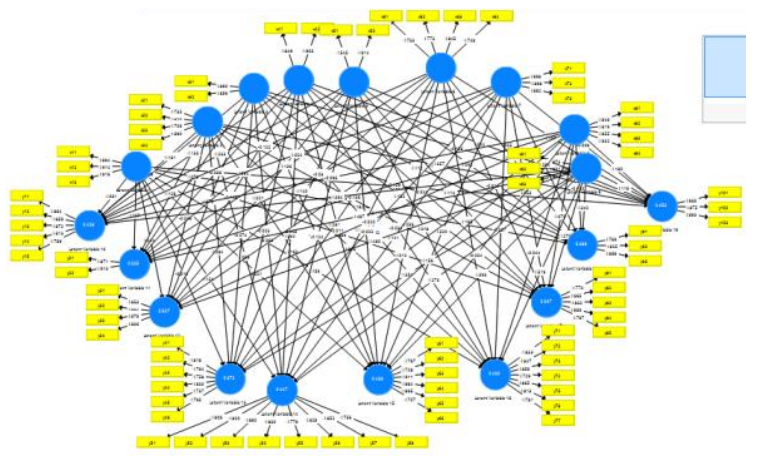

Fig 1. Model Implementation Policy with Safety Culture Dimensions
From the picture above in blue are variable and yellow are the indicators. From the picture above can be seen that all the indicators reflect its variable each variable $\mathrm{X}$ with the details as follows:

a. Communication reflected by 3 (three) indicators

b. Resources reflected by 4 (four) indicators

c. Disposition reflected by two (2) indicators

d. Structure of Bureaucratic is reflected by two (2) indicators

e. Weak implementation of the policy is reflected by two (2) indicators

f. Cost of Safety is reflected by four (4) indicators g. Supervision is reflected by two (2) indicators

h. Audit reflected by 4 (four) indicators

i. Sanctions reflected by 3 (three) indicators

\section{And variable $Y$ as follows:}

a. Leadership is reflected by five (5) indicators

b. Policy is reflected by two (2) indicators

c. The strategy is reflected by four (4) indicators

d. Workers reflected by six (6) indicator

e. The process is reflected by 8 (eight) indicators

$\mathrm{f}$. Behavior is reflected by six (6) indicator

g. K3 costs reflected by seven (7) indicator

h. Contract system is reflected by four (4) indicators i. System value is reflected by of four (4) indicators

j. Partnership is reflected by five (5) indicators

On the path coefficient table above, to see the significance of influence between the variables it needs to be seen the value of its t-value (T Statistic) having a value> 1.96. For example, policies affecting Behavior has a 0723 value $<1.96$, it can be said to Conduct Policy has no significance influence.

Based on the results of Smartpls 3.0 by bootstrapping method (Path Coeffisien), then the relationship between Dimension Implementation Significant policy as variable $\mathrm{X}$ with Safety Culture as a variable $\mathrm{Y}$ obtained are as follows .:

Table 2. Significant reliationship between the variables

\begin{tabular}{|l|c|c|}
\hline $\begin{array}{l}\text { Relationship variabel of } \\
\text { implementation safety } \\
\text { management system with } \\
\text { variabel safety culture }\end{array}$ & T Statistic & Result \\
\hline Supervision --> Behavior & 1.983 & Significant \\
\hline Sanction --> Leadership & 2.099 & Significant \\
\hline Sanction --> Worker & 2.123 & Significant \\
\hline Sanction --> Behavior & 2.634 & Significant \\
\hline Sanction --> Strategy & 3.046 & Significant \\
\hline Sanction --> Cost of Safety & 3.104 & Significant \\
\hline Sanction --> Policy & 3.254 & Significant \\
\hline
\end{tabular}

Terms fulfill significance ( $\mathrm{T}$ Statistic> 1.96) at 7 relationships between dimensions variable $\mathrm{X}$ to variable $\mathrm{Y}$. Based on the table above, it can be 
described model of inter-dimensional pattern of significant relationships and interplay as follows:

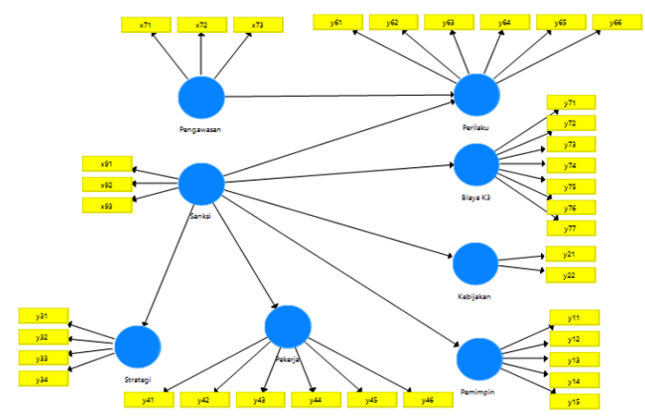

Fig 2. Model Implementation of Safety Policy in Construction

7 is a significant relationship above are the findings of this research will be discussed as follows:

\section{Supervision has a significant relationship to behavior}

This relationship meets the hypothesis $\mathrm{H} 1$ Supervision (X7) and Sanctions (X9) positive and significant impact on the Conduct (Y5). By Yusri Heni in his book "Improving Our Safety Culture" (2011), monitoring is done to ensure compliance with safety requirements, so the condition and behavior do not survive that can result in an accident can be detected early on. Supervision is done properly, carefully and responsibly and fully supported by the management will have an impact on long-term jobs were saved, which provide assurance of safety and tranquility for workers, communities and the environment. Supervision is required in order to avoid disruption to the work due to the condition and behavior do not survive or unsafe. To control internal and external oversight is required. According Wirahadikusumah (2006) supervision by the regulatory Directorate of Occupational Health and Safety Norms (PNK3), the Ministry of Labor is still lacking due to a lack of supervisory personnel. According to the Secretary General of the Ministry of PUPR, intensive surveillance may facilitate the implementation of $\mathrm{K} 3$ because during this new surveillance carried out if there are events. According to the expert supervision must be done by competent personnel. While the Yusri Heni stated that a supervisor should be a part of a technical or field personnel who are experienced so that it has the technical competence and also competence K3. Besides the technical approach, too personal and persuasive approach is needed to improve the behavior of K3. To improve the behavior of $\mathrm{K} 3$, other than supervision is also necessary training so that knowledge and awareness of K3 good behavior and properly inflated. In the Minister of Public Works No. 05 / PRT / M / 2014 on Guidelines for Management System Occupational
Health and Safety (SMK3) Construction Sector Public Works stipulated that the Ministry PUPR supervising the implementation of RK3K and performance evaluation SMK3 Construction Sector PU, conducted by Officer commitments (KDP) and assisted by expert K3 Construction / Officers K3 Construction of internal and / or external to the organization PPK.

\section{The sanctions have a significant relationship to the Cost $\mathrm{K3}$}

This significant relationship satisfy the hypothesis H1: Sanctions (X9) positive and significant impact on the Cost K3 (Y7). Sanctions relating to the implementation of $\mathrm{K} 3$ is set in the Minister of Public Works No. 05 of 2014 and the Circular Letter of the Minister of Public Works No. 66, 2015. In the Regulation of the Minister of Public Works No. 052014 Article 21, stated that the Committing Officer (CO) who do not implement the rules SMK3 as mandated under this Regulation, the Administrative sanctions may be imposed in accordance with prevailing regulations. In addition, in a Circular Letter of the Minister of Public Works No. 66 In 2015, H. SANCTIONS points, mentioned that the Committing Officer (CO) who do not carry this notice will be subject to administrative sanctions in accordance with the provisions of the legislation.

\section{The sanctions have a significant relationship to Policies}

This significant relationship satisfy the hypothesis H1: Sanctions (X9) positive and significant effect on policy (Y2). Sanctions relating to the implementation of K3 is set in the Minister of Public Works No. 05 of 2014 and the Circular Letter of the Minister of Public Works No. 66, 2015. In the Regulation of the Minister of Public Works No. 05 2014 Article 21, stated that the Committing Officer (CO) who do not implement the rules SMK3 as mandated under this Regulation, the Administrative sanctions may be imposed in accordance with prevailing regulations. In addition, in a Circular Letter of the Minister of Public Works No. 66 In 2015 , H. SANCTIONS points, mentioned that the Committing Officer (CO) who do not carry this notice will be subject to administrative sanctions in accordance with the provisions of the legislation.

\section{Sanctions have a significant relationship to Leadership}

This significant relationship satisfy the hypothesis H1: Sanctions (X9) positive and significant impact on Leadership (Y1). Sanctions relating to the implementation of $\mathrm{K} 3$ is set in the Minister of Public Works No. 05 of 2014 and the Circular Letter of the Minister of Public Works No. 
66, 2015. In the Regulation of the Minister of Public Works No. 052014 Article 21, stated that the Committing Officer (CO) who do not implement the rules SMK3 as mandated under this Regulation, the Administrative sanctions may be imposed in accordance with prevailing regulations. In addition, in a Circular Letter of the Minister of Public Works No. 66 In 2015, H. SANCTIONS points, mentioned that the Committing Officer (CO) who do not carry this notice will be subject to administrative sanctions in accordance with the provisions of the legislation.

\section{The sanctions have a significant relationship to the Worker}

This significant relationship satisfy the hypothesis H1: Sanctions (X9) positive and significant impact on the Human / Workers (Y4). Sanctions relating to the implementation of K3 is set in the Minister of Public Works No. 05 of 2014 and the Circular Letter of the Minister of Public Works No. 66, 2015. In the Regulation of the Minister of Public Works No. 052014 Article 21, stated that the Committing Officer (CO) who do not implement the rules SMK3 as mandated under this Regulation, the Administrative sanctions may be imposed in accordance with prevailing regulations. In addition, in a Circular Letter of the Minister of Public Works No. 66 In 2015, H. SANCTIONS points, mentioned that the Committing Officer (CO) who do not carry this notice will be subject to administrative sanctions in accordance with the provisions of the legislation.

\section{The sanctions have a significant relationship to the Behavior}

This significant relationship satisfy the hypothesis H1: Sanctions (X9) positive and significant impact on the Conduct (Y5). According to Mathis (2012), sanctions or penalties are designed to stop the bad behavior. The use of sanctions to stop the bad behavior of $\mathrm{K} 3$ will be effective if it is dropped at the right time and consistently. As for the start behavior $\mathrm{K} 3$ correct or improve the safety culture requires training, guidance and good auditing (Yusri Heni, 2011). Sanctions relating to the implementation of K3 is set in the Minister of Public Works No. 05 of 2014 and the Circular Letter of the Minister of Public Works No. 66, 2015. In the Regulation of the Minister of Public Works No. 05 2014 Article 21, stated that the Committing Officer (CO) who do not implement the rules SMK3 as mandated under this Regulation, the Administrative sanctions may be imposed in accordance with prevailing regulations. In addition, in a Circular Letter of the Minister of Public Works No. 66 In 2015, H. SANCTIONS points, mentioned that the Committing Officer (CO) who do not carry this notice will be subject to administrative sanctions in accordance with the provisions of the legislation. Sanctions on these two regulations only set of administrative sanctions against the KDP but have not set up sanctions against contractors who do not carry $\mathrm{K} 3$ in its work. In addition to the necessary sanctions also an award or reward for the KDP nor the contractors who successfully applied K3 and zero accident in the project. This would encourage the KDP (eg a promotion or recommendation of a promotion, the ease of getting loans or mortgages) and the contractor (gold pin, reward in the form of money) in building $\mathrm{K} 3$ behavior is good and right.

\section{Sanctions have a significant relationship to the Strategy}

This significant relationship satisfy the hypothesis H1: Sanctions (X9) positive and significant impact of the Strategy (Y3). Sanctions itself is one strategy to improve the safety culture.

In order for the regulation to be effective and properly implemented on the ground then the K3 guidelines should be included in the articles of the contract. So if there organizer construction workers infringing may be subject to sanctions.

According to Ho and Zeta (2004), the safety culture in each country influenced the culture of the country. The findings of the above study (if referring to Ho and Zeta) shows that the perception of respondents representing environment Ministry PUPR generally have the perception that the strict supervision and sanctioning the firm in implementing policies SMK3 can effectively enhance the safety culture in the projects of the building, housing, water resources, roads and bridges in Indonesia.

Given the above results, it is necessary to recommend improvements to the PU Candy No. 05 / PRT / M / 2014, namely:

a. Supervision is done by the competent potentially influence a person's behavior. In this case the PIC or its stakeholders is the Committing Officer (CO).

b. Sanctions related to the value of the fee $\mathrm{K} 3$ is very influential. PIC or its stakeholders is the Committing Officer (CO).

c. Sanctions could be attributed to persyaratan2 implementation of the work (in the offer). PIC or its stakeholders is the Committing Officer (CO).

d. Sanctions and rewards (punishment and reward) which unequivocally demonstrate leadership. PIC or its stakeholders is the Committing Officer (CO).

e. Sanctions and rewards (punishment and reward) that does not educate can or will be emulated by workers. PIC or its stakeholders is the Committing Officer (CO).

f. Cultural habits or K3 can be adopted behavior. PIC or its stakeholders is the Committing Officer (CO). 
g. Short or long term strategy is influenced by the form of sanctions and rewards (punishment and reward) is applied. PIC or its stakeholders is the Committing Officer (CO).

h. K3 costs as a form of collateral as "Performance Bond" as a complement to the policy control element.

\section{CONCLUSION}

After doing the analysis and conclusions of this study include:

1. Policy Health and Safety Management System (SMK3) relating to the Norms, Standards, Procedures and Criteria (NSPK) in Indonesia to improve the safety culture is as follows:

Norm:

1. Government Regulation (PP) 50 Year 2012 on Implementation of salvation and Health Management System (SMK3).

2. Regulation of the Minister of Public Works No. 05 / PRT / M / 2014 on Guidelines for Safety and Health Management System (SMK3) Construction Sector Public Works.

Guidelines or procedures:

1. Regulation of the Minister of Manpower No. $26 / 2014$ on the Implementation of Application Assessment Management System Occupational Health and Safety (SMK3).

2. Regulation of the Minister of Public Works No. 05 / PRT / M / 2014 on Guidelines for Safety and Health Management System (SMK3) Construction Sector Public Works.

While Standard and Criterion is still in the drafting process by the Ministry of Public Works and Public Housing.

Recommendations for policy improvement associated with increased Safety Culture and fill the shortfall / gap from existing policies, are as follows:

- Supervision is done by the Committing Officer (CO) competent can encourage cautious behavior (safe) in the project.

- Sanctions related to the value or money is very influential on $\mathrm{K} 3$ fee.

- Penalties may be associated with persyaratan2 implementation of the work (in the offer) does not have to be directly related to costs, in the bidding documents.

- The sanctions that unequivocally demonstrate the authority of leaders (Leadership).

- Sanctions are not educating can or will be emulated by workers, otherwise strict sanctions and educate would encourage workers to be careful not to break the rules.

- Penalties may stop the behavior or habit that is wrong.
- Short or long-term strategy is influenced by the form of sanctions.

- Implementation of K3 pledged as collateral as "Performance Bond" in the bidding documents.

\section{SUGGESTION}

The suggestion from this study include:

a. This research can be used in order to formulate policies and cultural dimensions of safety, especially in the field of construction services which have the highest rate of employment accident compared to other sectors.

b. Supervision of the Central Government, especially the Ministry concerned (Ministry of Labor and Ministry of Public Works and Public Housing) with the development of the construction sector should really be applied with discipline.

c. Costs in the implementation of $\mathrm{K} 3$ is not affiliated with the project implementation costs but serve as a prerequisite so that if there is no allocation of costs for the $\mathrm{K} 3$ in the offer, it could be penalized or excluded from the list of bidders.

d. Need to do further research on the effects of supervision over the behavior of workers and all stakeholders and the effect of sanctions against the leadership, sanctions against Labor, sanctions against Conduct, sanctions against the strategy, sanctions against fee K3, sanctions against the policy involving the parties determinant of government policy through focusing Delphi group discussion round that the results of this could be a research recommendation improvement policy which can later be applied in Indonesia.

e. Need to do research related to the subsequent indepth review and complete the $\mathrm{K} 3$ regulations such as PP 50/2012, Regulation of Ministry 26 year 2014 and Regulation of Ministry Public of Work 5/2014.

\section{REFERENCES}

[1] Alasamri, H. et al. 2012. "A Framework for Enhancing and Improving the Safety Culture on Saudi Construction Sites". Heriot-Watt University, School of the Built Environment, Institute of Infrastructure \& Environment, Edinburgh, EH14 4AS, UK

[2] Andi et.al. 2005, "Model Persamaan Struktural Pengaruh Budaya Keselamatan Kerja pada Perilaku Pekerja di Proyek Konstruksi”, Jurnal Teknik Sipil, [online], Vol. 12 No. $3 . \quad$ Dari: http://www.ftsl.itb.ac.id/. [1 Mei 2014]

[3] Andi. 2008. Construction Workers Perceptions Toward Safety Culture. CED, Vol. 10, No. 1, March 2008, pp. 1-6. Petra Christian University : Indonesia.

[4] Biggs, Sarah E. et al. 2013. "Safety leaders' perceptions of safety culture in a large 
Australasian construction organization". Safety Science, 52, pp. 3-12. Elsevier Ltd.

[5] Chen, P. et al. 2009. Cross-Cultural Understanding of Construction Project Managers' Conceptions of Their Work [online]. Available from : ascelibrary.org by Universitas Indonesia [Accessed 4 November 2015].

[6] Chinda, T. 2007. A System Dynamics Approach To Construction Safety Culture. Griffith University : Australia.

[7] Chinda, T., \& Mohamed, S. 2007. Causal Relationships Between Enablers Of Construction Safety Culture. Fourth International Conference on Construction in the 21st Century (CITC-IV) "Accelerating Innovation in Engineering, Management and Technology" July 11-13, 2007, Gold Coast, Australia

[8] Chinda, T., \& Mohamed, S. 2007. "Structural equation model of construction safety culture". Engineering, Construction and Architectural Management Vol. 15 No. 2, 2008 pp. 114-131. Emerald Group Publishing Limited

[9] Choudhry, R.M. et al. 2006. "The nature of safety culture: A survey of the state-of-theart”. Safety Science 45 (2007) 993-1012. Elsevier Ltd.

[10] Choudhry, R.M. et al. 2007. Developing a Model of Construction Safety Culture [online]. Available from : ascelibrary.org by Universitas Indonesia [Accessed 11 February 2016].

[11] Christina, Wieke Yuni,dkk, 2012. "Pengaruh Budaya Keselamatan dan Kesehatan Kerja (K3) terhadap Kinerja Proyek Konstruksi”, Jurnal Rekayasa Sipil / Volume 6, No. 1 - 2012 ISSN 1978 - 5658

[12] Cooper, M. D. (2000). "Toward a model of Safety Culture". Safety Science, 36, 111-136.

[13] Fang, D., \& Wu, H. 2012. "Development of a Safety Culture Interaction (SCI) model for construction projects". Safety Science 57 (2013) 138-149. Elsevier Ltd.

[14] Frazier, C, B. et al. 2011. "A hierarchical factor analysis of a safety culture survey". Journal of Safety Research 45 (2013) 1528. Elsevier.ltd.

[15] Fu, Y, K., \& Chan, T, L. 2013. "A conceptual evaluation framework for organisational safety culture: An empirical study of Taipei Songshan Airport". Journal of Air Transport Management 34 (2014) 101-108. Elsevier Ltd.
[16] Ghaderi, R., \& Kasirossafar, M. 2011. Construction Safety in Design Process [online]. Available from : ascelibrary.org by Universitas Indonesia [Accessed 30 Januari 2015].

[17] Gilkey, D, P. et al. 2012. "Comparative Analysis of Safety Culture Perceptions among Home Safe Managers and Workers in Residential Construction". ASCE Journal of Construction Engineering Management, 2012, 138(9): 1044-1052.

[18] Ghozali, Prof. Dr. Imam, M.Com., Ak. 2005. Model Persamaan Struktural. Semarang: Badan Penerbit Universitas Dionegoro.

[19] Hills, M, J. et al. 2006. "Factors Influencing The Development Of Hong Kong's Construction Industry: A Qualitative Study". ResearchGate.

[20] Ho, J, K, L., \& Zeta, K, C. 2004. "Cultural factors and their Significance to the Hong Kong Construction Industry" [online]. Available from: http://www.ic.ployu.edu.hk/ esh/kb/culture/Ho\&Zeta.pdf [Accessed 20 September 2004].

[21] International Atomic Energy Agency. 2011. Safety Culture and Organizational Change Management. February 15-18, 2011, IAEA Headquarters - Vienna

[22] Ishak, F. Ahmad, N. Isnaini Janipha, N.A. dan Ismail, R. (2012). "Assessing the Behavioural Factors' of Safety Culture for the Malaysian Construction Companies". Proceedings ASEAN Conference on Environment-Behaviour Studies (AcE-Bs 2011), Bandung, Indonesia

[23] Ismail, F. et al. 2010. A Framework of Safety Culture for the Malaysian Construction Companies: A Methodological Development. Malaysia

[24] Ismail, Z. et al. 2012. "Factors influencing the implementation of a safety management system for construction sites". Safety Science 50 (2012) 418-423. Elsevier Ltd.

[25] Jayatri, E, A. 2014. "Faktor Individu dan Faktor Pembentuk Budaya Keselamatan dan Kesehatan Kerja (K3) dengan Perilaku K3 di Unit Operasional PT Bukit Asam (Persero) Tbk UPTE Tahun 2014". Universitas Sriwijaya : Indonesia.

[26] Kanchana, S. et al. 2015. "Studies on Labour Safety in Construction Sites". Hindawi Publishing Corporation, The Scientific World Journal Volume 2015, Article ID 590810, 6 pages. 
[27] Kirwan, B. (1998). Safety management assessment and task analysis-a missing link. Safety management: The challenge of change. Elsevier, Oxford, 67-92.

[28] Kurniasih, D., \& Rachmadita R, N. 2013. Pengukuran Budaya K3 Pada Tingkat Non Manajerial Dengan Menggunakan Cooper's Reciprocal Safety Culture Model Di PT. X. J@TI Undip, Vol VIII, No 2, Mei 2013. Indonesia.

[29] Maloney, W. F., \& Smith, G, R. 2003. "Reciprocal Determinism Model of Safety" ASCE Construction Research

[30] Mohamed, S., \& Chinda, T. 2007. "Organizational Safety Culture: A System Dynamics Approach". 4TH Triennial International Conference Rethinking and Revitalizing Construction Safety, Health, Environment and Quality Port Elizabeth South Africa 17-20 May 2005 ISBN 0-620 -33919-5 pp. 282 -292.

[31] Molenaar, K.R, Park, J. and Washington, S. (2009) "A Framework for Measuring Corporate Safety Culture and Its Impact on Construction Safety Performance" ASCE Journal of Construction Engineering Management, 135(6), 488-496.

[32] Muñiz, B, F. et al. 2007. Safety culture: Analysis of the causal relationships between its key dimensions. Elsevier, Journal of Safety Research 38 (2007) 627641

[33] Nielsen, K, J. 2013. "Improving safety culture through the health and safety organization: A case study". Journal of
Safety Research 48 (2014) 7-17. Elsevier Ltd.

[34] Parker, D. et al. 2005. A framework for understanding the development of organisational safety culture. Elsevier.ltd.

[35] Pungvongsanuraks, P. et al. 2010. "Exploratory Factor Analysis of Safety Culture in Thai". Proceedings of the 2010 International Conference on Engineering, Project, and Production Management Construction Industry.

[36] Raheem, A. A., \& Issa R. R. A. 2015. Safety implementation framework for Pakistani construction industry. Elsevier.ltd.

[37] Seo, H, C. et al. 2014. Analyzing safety behaviors of temporary construction workers using structural equation modeling. Elsevier.ltd.

[38] Siu, O. et al. 2002. "Safety climate and safety performance among construction workers in Hong Kong The role of psychological strains as mediators". Accident Analysis and Prevention 36 (2004) 359-366. Elsevier Ltd.

[39] Tam, V, W, Y., \& Fung, I, W, H. 2012. Behavior, Attitude, and Perception toward Safety Culture from Mandatory Safety Training Course [online]. Available from : ascelibrary.org by Universitas Indonesia [Accessed 4 April 2015].

[40] Zou, P. X. W. 2011. "Fostering a Strong Construction Safety Culture". Leadership and Management in Engineering 2011, 11(1): 11-22. Ascelibrary.org 